\title{
Pollen Morphology and Protein Pattern of Nitraria retusa and Some Selected Taxa of Zygophyllaceae in Egypt
}

\author{
H. EL-Atroush*, A.E. EL-Shabasy ${ }^{* *}$, M.A. Tantawy ${ }^{*}$ and \\ H.M.S. Barakat* \\ *Botany Department., Faculty of Science, Ain Shams \\ University and ${ }^{* *}$ Botany Department, Faculty of Education, \\ October University, A.R.E.
}

\begin{abstract}
D OLLEN morphology and pattern of Nitraria retusa (Forssk.) Asch. were studied and compared against eight selected taxa of Zygophyllaceae viz. Fagonia arabica, F. cretica, Peganum harmala, Tribulus terrestis, Zygophyllum album, Z. coccenium, Z. decumbens and Z. simplex using Scanning Electron Microscope (SEM) and sodium dodecyle sulphate-polyacrylamide gel electrophoresis technique (SDS-PAGE). A wide range of measurements were obtained from digitized SEM images of whole pollen grains and exine pattern. Twenty nine protein bands were obtained with $100 \%$ polymorphism among the species examined. $F$. arabica and $T$. terrestis were characterized by one positive unique band with a molecular weight 56.8 and $24 \mathrm{kDa}$ respectively. $P$. harmula was characterized by two positive unique bands with a molecular weight 62 and $42 \mathrm{kDa}$. $N$. retusa was characterized by three positive unique bands with amolecular weigh 64.6, 60.7 and $36 \mathrm{kDa}$. A dendrogram was constructed based on the similarity data matrix by unweighted pair group method using arithmetic averages cluster analysis. SEM and protein pattern analysis recommended the separation of Nitraria retusa (Forssk.) Asch. besides Fagonia sp. into a distinct family.
\end{abstract}

Zygophyllaceae is a small family with 27 genera and 250 species, distributed in the arid and semi-arid regions of the tropics. Plants included are small trees, shrubs or sub-shrubs (Sheahan \& Cutler, 1993 and Ghazanfar, 1994). N. retusa (Forssk) belongs to the family Nitrariaceae where it is the only genus of this family (Täckholm, 1974 and Boulos, 2000) or to the family Zygophyllaceae (Zohary, 1972). Zygophyllaceae belongs to Geraniales and is divided into seven subfamilies Engler, (1931). Ronse Decraene and Smets (1991), Ronse Decraene et al., (1996) separated Nitraria retusa from Zygophyllaceae based on the study of floral development and vascular anatomy (Hussein et al., 2009). More investigation of the morphology, palynology, cytology and biochemistry have shown the family to be very heterogeneous (Sheahan and Cutler, 1993). Zygophyllaceae in the classification of Sheahan and Chase (1996) is subdivided into five subfamilies and about 27 genera and they recommended recognizing Nitraria and Peganum as two distinct families, belonging to the order Sapindales and not being closely related to Zygophyllaceae based on morphological and anatomical data. According to Hutchinson (1967), Goldberg (1986) and Zohary 
(1987) Zygophyllaceae was treated as a homogenous family including the Nitrariaceae, while the latter was treated by several authors as a distinct family (Täckholm, 1974; Sheahan and Cutler, 1993; Bolous, 2000 and Dahlgren, 1980; 1983 and 1989).

Taxonomists and paleobotanists have recognized the importance of pollen development and morphology in the identification and classification of plants (Martens and Fetz, 1980; Raj, 1983; Blackmore, 1981 and Doyle \& Walker, 1975). The study of pollen grains and spores morphology has provided a great wealth of phylogenetically useful information which played an important role in problems of botanical identification especially angiosperm systematic and phylogeny (Van Campo, 1966; 1967 and Doyle and Walker, 1975).

Proteins are the primary products in the realization of hereditary information and reflect the genetic structure of the organism the most precisely (Konarev, 1983). One of the methods for detecting the molecular heterogeneity is SDSPAGE, which is the most frequently employed techniques for separating and identifying the proteins according to their molecular weights (Haidar et al., 2013; Moradpour et al., 2014 and Savithiry, 2014). Electrophoretic separation of seed proteins is a powerful and efficient tool in addressing taxonomic and evolutionary relationships at both species and subspecies levels (Ladizinsky \& Hymowitz, 1979 and Badr et al., 1995 \& 2000). Variation in seed protein electrophoretic patterns proved useful in re-assessing the species relationships in a number of genera; Zygophyllum (EL-Ghamery et al., \& Khafagi, 2003) and Tribulus (Amal, 2006).

The aim of present study was to reveal the characterization and relationships among nine species of Zygophyllaceae viz. N. retusa, F. arabica, F. cretica, $P$. harmala, T. terrestis, Z. album, Z. coccenium, Z. decumbens and $Z$. simplex by using SEM and SDS-PAGE.

\section{Material and Methods}

\section{A- Pollen morphology}

Pollen grains of the selected plant species were collected from different regions according to Table 1 and identified according Täckholm (1974) and Boulos (1999).

Ideally, to obtain the maximum amount of systematic data from SEM studies of pollen, non acetolyzed materials were studied. Valuable systematic characters may be lost in acetolysis and true pollen shape may be greatly changed. The nonacetolysis technique was recommended owing to some of the pollen characters may be affected during the acetolysis technique such as pollenkitt (Hess, 1981 a; b) exineless pollen (Kress and Stone, 1982; 1983) and aperture morphology (Thanikaimoni, 1986). Study of fresh (non-acetolyzed pollen) can give greater 
insight into the functional significance of pollen characters which, in turn, can contribute to better systematic treatment (Tantawy et al., 2005).

Preparation of non-acetolyzed materials

mature pollen grains at anthesis were investigated using SEM (Skvarla, 1966). For SEM investigation conventionally air or critical point dried material was sputter coated (Hess, 1986). The terminology used in the description of pollen grains is generally based on that of Erdtman (1952), Faegri (1956), Kremp (1968) and Punt et al. (1994).

TABLE 1. Collection data.

\begin{tabular}{|c|l|l|}
\hline No. & \multicolumn{1}{|c|}{ Species } & \multicolumn{1}{c|}{ Locality } \\
\hline 1 & Fagonia arabica & Cairo-Suez road \\
\hline 2 & F. cretica & Burg El-Arab City-Alexandria \\
\hline 3 & Nitraria retusa & Pharaoh's Basins-Sinai \\
\hline 4 & Peganum harmala & Burg El-Arab City-Alexandria \\
\hline 5 & Tribulus terrestis & October 6 City-Giza \\
\hline 6 & Zygophyllum album & Rasheed City-Bahera \\
\hline 7 & Z. coccenium & Cairo-Suez Road \\
\hline 8 & Z. decumbens & Hagole Valley- Cairo-Suez Road \\
\hline 9 & Z. simplex & Cairo-Suez Road \\
\hline
\end{tabular}

\section{$B$ - SDS-PAGE of soluble seed storage protein}

Characterization and molecular mass determination of soluble seed storage proteins was carried out using one dimensional sodium dodecyl sulphate polyacrylamide gel electrophoresis (SDS-PAGE). Polyacrylamide slab gel (12\%) was prepared according to Laemmli (1970).

\section{Extraction of protein}

Samples were prepared for electrophoresis by grinding seeds to fine powder with pestle and mortar. Ten $\mathrm{mg}$ of the resulting powder was transferred to centrifuge tube, supplemented with $400 \mu \mathrm{l}$ extraction buffer and placed into a refrigerator for one hr. The extract was then centrifuged at $13000 \mathrm{rpm}$ for 10 min. at room temperature. The supernatant was transferred to new tube and used directly for electrophoresis or kept in a deep freezer until use within few days.

\section{Polyacrylamide gel preparation}

SDS polyacryamide gel slabs were prepared in the volumes given in Table 2. 
TABLE 2. Volume of solutions and buffers used for preparing $12 \%$ SDS polyacrylamide gel.

\begin{tabular}{|l|c|c|}
\hline \multicolumn{1}{|c|}{ Stock solution } & Separating gel & Stacking gel \\
\hline Acrylamide stock solution & $10 \mathrm{ml}$ & $1.33 \mathrm{ml}$ \\
\hline $\begin{array}{l}\text { Separating gel buffer } \\
(1.5 \mathrm{mM} \text { Tris/HCl pH 8.8) }\end{array}$ & $7.5 \mathrm{ml}$ & - \\
\hline $\begin{array}{l}\text { Stacking gel buffer } \\
(0.5 \mathrm{mM} \text { Tris/HCl pH 6.8) }\end{array}$ & - & $2.5 \mathrm{ml}$ \\
\hline $10 \%$ SDS & $0.3 \mathrm{ml}$ & $0.1 \mathrm{ml}$ \\
\hline Distilled water & $12 \mathrm{ml}$ & $6.1 \mathrm{ml}$ \\
\hline $10 \%$ ammonium persulphate & $150 \mu \mathrm{l}$ & $5 \mu 1$ \\
\hline $\begin{array}{l}\text { TEMED (N, N, N', N`-Tetramethyl } \\
\text { Ethylene diamine) }\end{array}$ & $10 \mu \mathrm{l}$ & $5 \mu 1$ \\
\hline Final volume & $30 \mathrm{ml}$ & $10 \mathrm{ml}$ \\
\hline
\end{tabular}

\section{Electrophoresis of protein}

Protein samples were prepared by mixing $10 \mu \mathrm{l}$ of clear protein extract with the same amount of $2 \mathrm{X}$ extract buffer $(2.5 \mathrm{ml}$ stacking gel buffer, $2 \mathrm{ml}$ glycerol or sucrose, $4 \mathrm{ml} \mathrm{10 \%} \mathrm{SDS} \mathrm{and} 1 \mathrm{ml} \beta$-mercaptoethanol made up to $10 \mathrm{ml}$ distilled water) and denatured by heating at $100^{\circ} \mathrm{C}$ for $2-3 \mathrm{~min}$. The samples were left to cool and $3 \mu$ l of Bromophenol blue dye were added. Electrophoresis was carried out in gel running buffer (15.15 g Tris base, $0.5 \mathrm{~g}$ SDS, $7.2 \mathrm{~g}$ glycine in $500 \mathrm{ml}$ distilled water) using a vertical gel electrophoresis unit (Model SE-400) trapped gas bubbles were purged away. Slab gel was prepared by pouring the separating gel between clamped glass plates, leave it for at least half hour to polymerize. After polymerization of the main gel, stacking gel solution was poured as an overlay to the separating gel to improve the tightness of protein banding. The gel was attached to the vertical electrophoresis tank system and equal amount of the samples $(12 \mu \mathrm{l})$ was loaded through electrode buffer into wells in the stacking gel layer. The upper tray was filled with the same buffer. Molecular weight marker $(5 \mu \mathrm{l})$ composed of 18- 66 KDa proteins (Fermentas protein ladder) were also loaded. Electrophoresis was carried out at $140 \mathrm{~V}$ for the first $15 \mathrm{~min}$. followed by $150 \mathrm{~V}$ until the indicator dye reached the bottom of the gel. Gels were stained overnight in $20 \mathrm{ml}$ Coomassie blue R 250 and de-stained by shaking overnight in de-staining solution $(500 \mathrm{ml}$ methanol and $100 \mathrm{ml}$ acetic acid made up to 1 Liter with dist. water). Gels were photographed, scanned and analyzed using Gel doc 2000 Bio-Rad system.

\section{A- Palynological characters}

\section{Results}

The main palynological characters of the studied species are listed in Table 3 and 4. Pollen grains were monad, isopolar and radially symmetrical. They showed diversity in shape, size, aperture type and exine characters.

Egypt. J. Bot., Vol. 55, No. 2 (2015) 
Pollen shap: the shape of pollen grains varied from perprolate, prolate and subprolate (Plate 1-4).

Pollen size: the studied pollen grains were either minute or small grains.

The amb shape: it was elliptic or circular to elliptic.

Apertures: tricircumcolporate except $T$. terrestis which appeared as monocryptoporous.

Aperture length and width: ranged from 4.56 to $12.7 \mu \mathrm{m}$ and from 0.05 to $5.8 \mu \mathrm{m}$ respectively.

Aperture surface level: either opening furrow, deeply slit or sunken.

Aperture memberane: granulated or not.

Exine sculpture: reticulate in all species except in $N$. retusa his striate.

Metareticulum: present or not.

Brochus type: homobrochate or heterobrochate.

Pollen kitt: either conspicuous, weak conspicuous or non-conspicuous.

The polar axis $(\mathrm{P})$ : the mean length of the polar axis $(\mathrm{P})$ was ranged from $5.74 \mu \mathrm{m}$ in $Z$. simplex to $19.73 \mu \mathrm{m}$ in $T$. terrestis.

The equatorial axis $(\mathrm{E})$ : the mean equatorial diameter was ranged from $3.31 \mu \mathrm{m}$ in Z. simplex to $16.9 \mu \mathrm{m}$ in $T$. terrestis.

$\mathrm{P} / \mathrm{E}$ axis type: ranged from longiaxe $(\mathrm{P} / \mathrm{E}>1.8)$ and semi-equiaxe $(\mathrm{P} / \mathrm{E}<1.8)$.

Apocolpium index: ranged from $0.33 \mu \mathrm{m}$ in $F$. cretica and $2.02 \mu \mathrm{m}$ in $Z$. simplex and absent in $T$. terrestis.

Mesocolpium: ranged from 0.65 in $Z$. decambens and $6.2 \mu \mathrm{m}$ in $N$. retusa respectively and absent in $T$. terrestis.

The muri: granulated or not, appeared as angustimurate, latimurate or lira.

The muri size (thickness): ranged from $0.08 \mu \mathrm{m}$ in $Z$. simplex to $2.11 \mu \mathrm{m}$ in $T$. terrestis but absent in $N$. retusa.

The sculptural density per unit area: present in $N$. retusa, ranged from 1 in $T$. terrestis to 29 in Z. simplex.

Lumina: generally irregular or circular in outline.

Lumina width (area): ranged from $0.13 \mu \mathrm{m}$ in $Z$. decambens to $0.73 \mu \mathrm{m}$ in $T$. terrestis but was absent in $N$. retusa.

\section{$B$ - Seed protein panding profile}

Seed protein banding profile is illustrated in Fig. 1. The total number of bands was 29 bands. The molecular weight of these bands ranged between 20 to $90.4 \mathrm{kDa}$. The bands detected in the nine studied species expressed as present (1) or absent (0) are given in Table 4. The highest number of bands was 14, detected in $P$. harmala, while the lowest number of bands was five detected in $F$. cretica. All the bands were polymorphic giving a $100 \%$ polymorphism among the species examined. The protein assay permitted the identification of only four species by unique positive markers. It shows that $F$. arabica and $T$. terrestis were characterized by one positive unique protein band with molecular weight of 56.8 and $24 \mathrm{kDa}$ respectively, while three positive unique bands with molecular weight 64.6, 60.7 and $36 \mathrm{kDa}$ associated $N$. retusa. On the other hand, species $P$. harmala was characterized by two positive unique bands with a molecular weight of 62 and $42 \mathrm{kDa}$. 


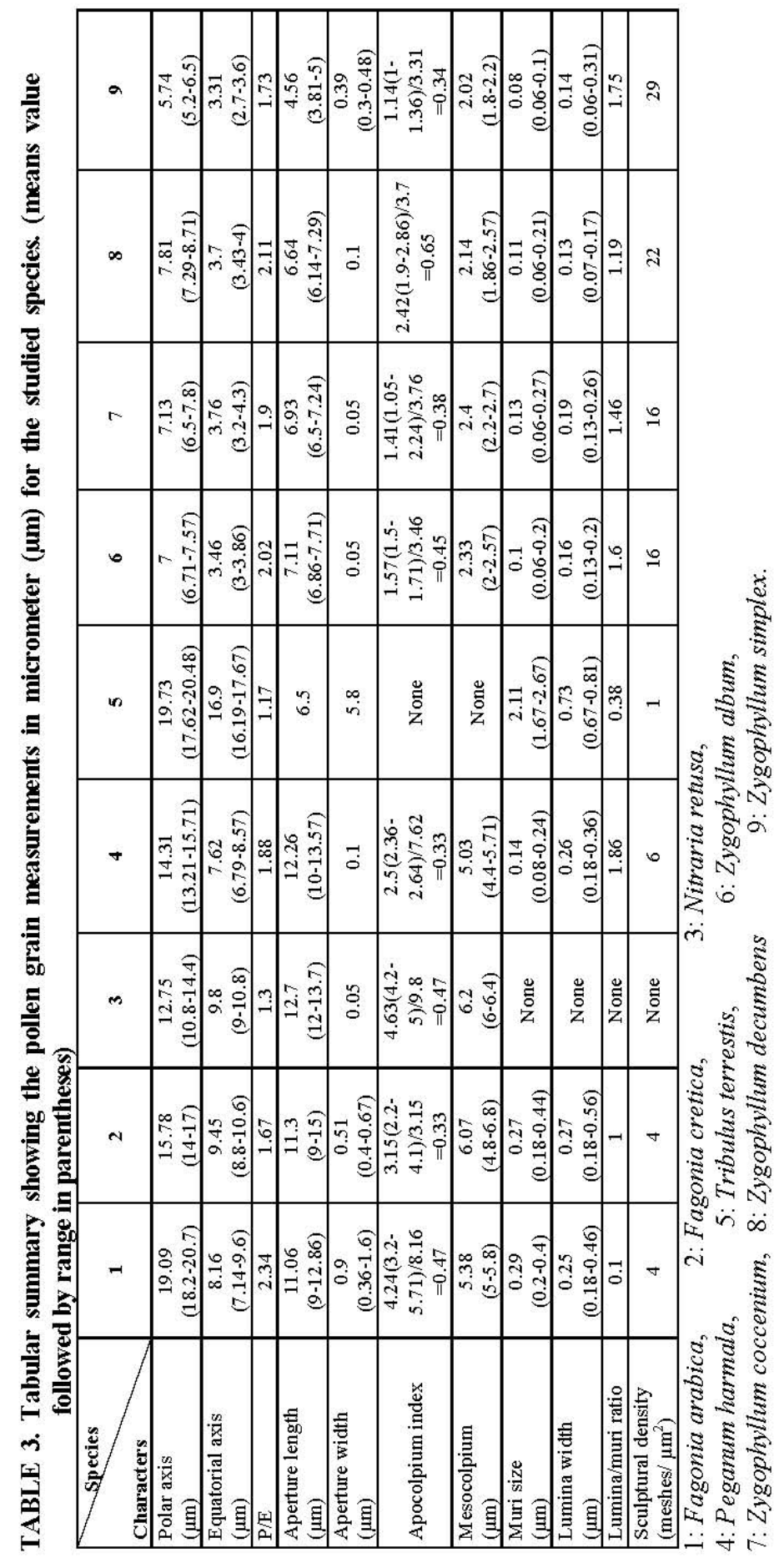

Egypt. J. Bot., Vol. 55, No. 2 (2015) 
POLLEN MORPHOLOGY AND PROTEIN PATTERN OF ...

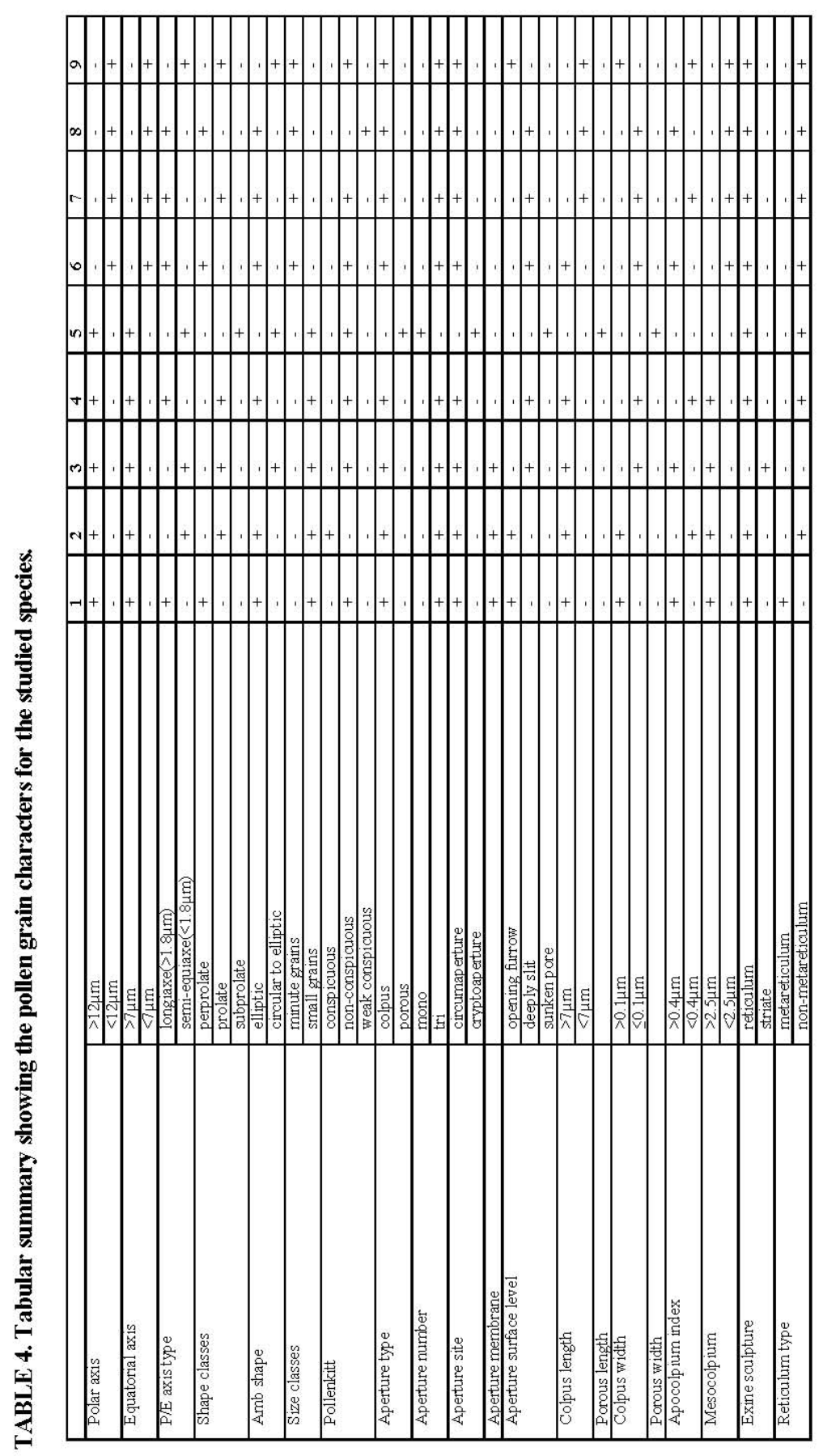

Egypt. J. Bot., Vol. 55, No. 2 (2015) 


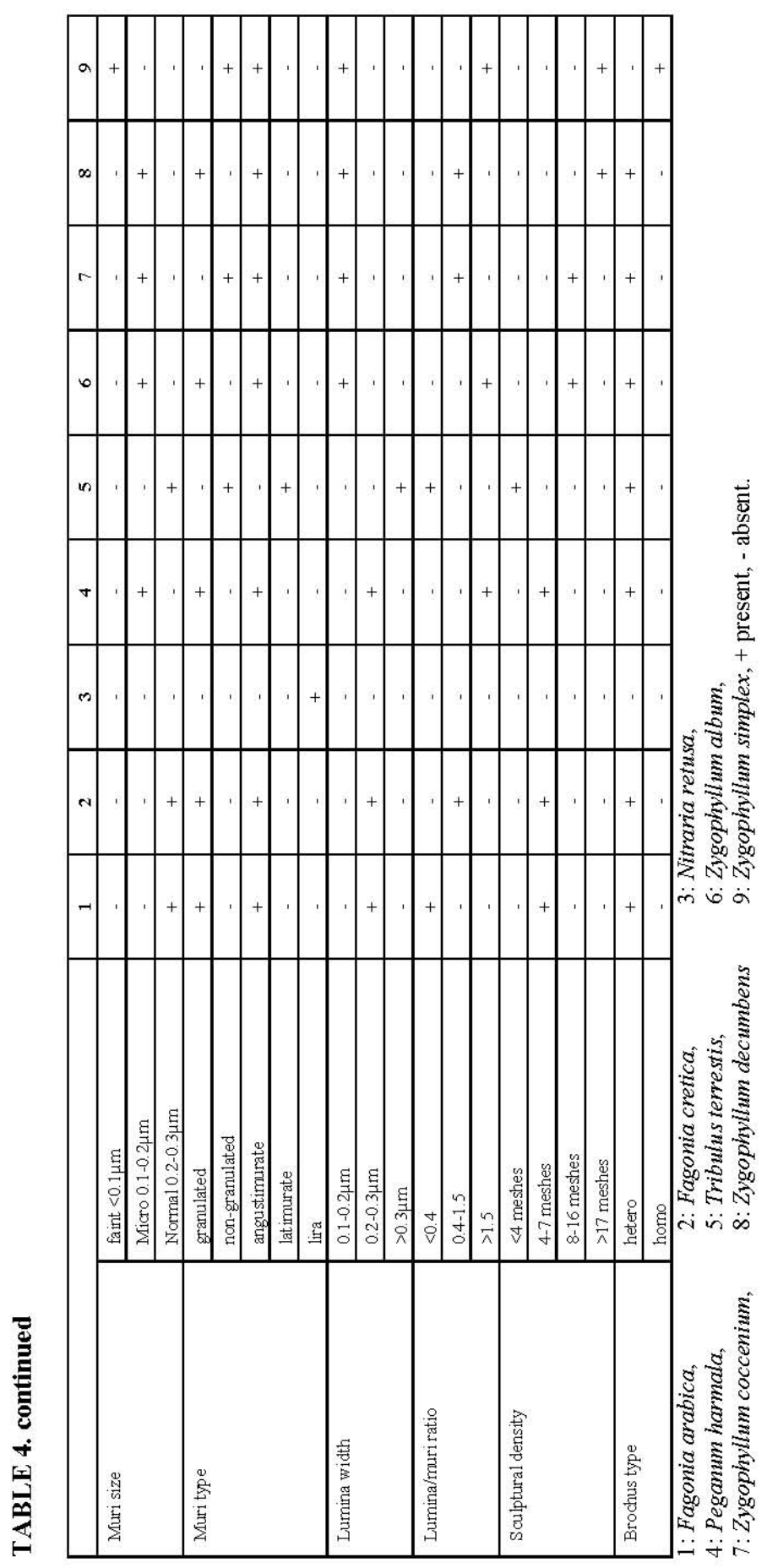

Egypt. J. Bot., Vol. 55, No. 2 (2015) 


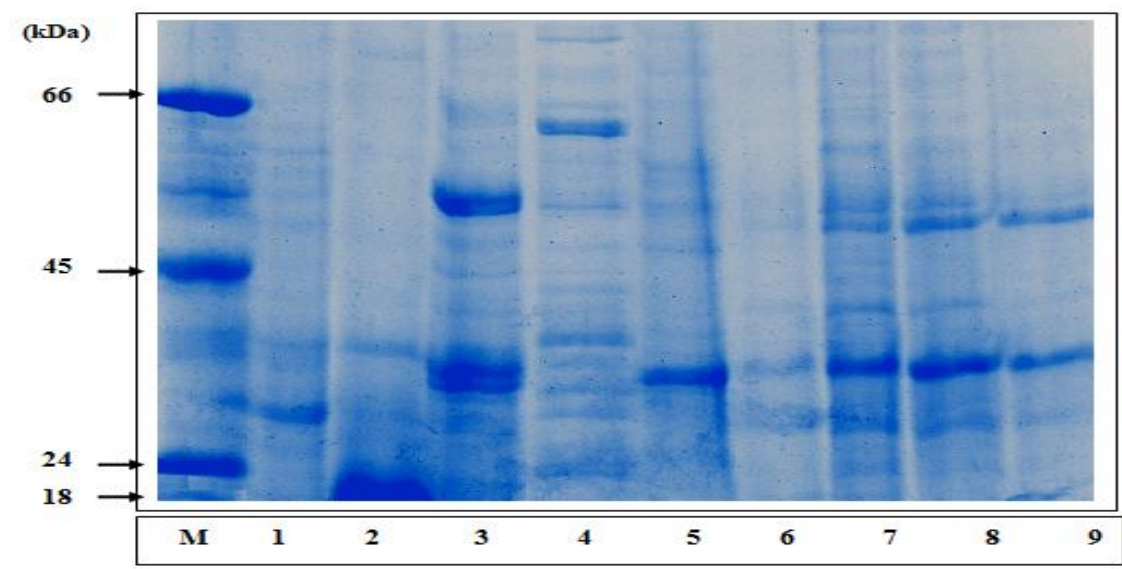

Fig. 1. Electrophoretic total soluble protein pattern of studies species M: marker,
1: Fagonia arabica,
2: F. cretica,
3: Nitraria retusa,
4: Peganum harmala
5: Tribulus terrestis,
6: Zygophyllum album
7: Z. coccenium,
8: Z. decumbens
9: Z. simplex.

Genetic relationships among the studied species as revealed by protein analysis

According to similarity matrix of protein analysis, the highest similarity value (0.93) was recorded between $Z$. coccenium and $Z$. decumbens indicating that these two species were closely related to each other. On the other hand, the lowest similarity value (0.38) was recorded between $P$. harmala and $Z$. decumbens indicating that these were distantly related species Table 5.

\section{Cluster analysis}

The out put of SAHN-clustering program was presented in the form of a phenogram by using the tree display graphic (TREE). The resulting dendrogram revealed by pollen morphology (Fig. 2) showed that the studied species have an average taxonomic distance of about 1.53. At this level T. terrestis is separated from other species. The remaining species are differentiated into two main lines at a distance of about 1.332. At group (1) N. retusa is split off at 1.178 level. At a distance close to 0.948 , the remaining species; $F$. arabica and $F$. cretica are delimited as a sub-group which $P$. harmala is split off. On the other hand, at a distance close to 1.156 , the remaining species; $Z$. album, Z. cocenium and $Z$. decumbens are delimited as a sub-group which $Z$. simplex is split off.

TABLE 5. Genetic similarity matrix of studied species for protein analysis.

\begin{tabular}{|l|c|c|c|c|c|c|c|c|c|}
\hline & $\begin{array}{c}F . \\
\text { arabica }\end{array}$ & $\begin{array}{c}\boldsymbol{F} . \\
\text { cretica }\end{array}$ & $\begin{array}{c}\boldsymbol{N} . \\
\text { retusa }\end{array}$ & $\begin{array}{c}\boldsymbol{P} . \\
\text { harmala }\end{array}$ & $\begin{array}{c}\boldsymbol{T} . \\
\text { terrestis }\end{array}$ & $\begin{array}{c}\boldsymbol{Z} . \\
\text { album }\end{array}$ & $\begin{array}{c}\boldsymbol{Z} . \\
\text { coccenium }\end{array}$ & $\begin{array}{c}\boldsymbol{Z} \text {. } \\
\text { decumbens }\end{array}$ & $\begin{array}{c}\boldsymbol{Z} \text {. } \\
\text { simplex }\end{array}$ \\
\hline F. arabica & 1.00 & & & & & & & & \\
\hline F. cretica & 0.72 & 1.00 & & & & & & & \\
\hline N. retusa & 0.45 & 0.45 & 1.00 & & & & & & \\
\hline P. harmala & 0.48 & 0.48 & 0.48 & 1.00 & & & & & \\
\hline T. terrestis & 0.48 & 0.55 & 0.55 & 0.66 & 1.00 & & & & \\
\hline Z. album & 0.70 & 0.62 & 0.62 & 0.52 & 0.66 & 1.00 & & & \\
\hline Z. coccenium & 0.66 & 0.52 & 0.45 & 0.41 & 0.55 & 0.76 & 1.00 & & \\
\hline Z. decumbens & 0.62 & 0.55 & 0.41 & 0.38 & 0.52 & 0.72 & 0.93 & 1.00 & \\
\hline Z. simplex & 0.83 & 0.70 & 0.55 & 0.52 & 0.66 & 0.79 & 0.83 & 0.79 & 1.00 \\
\hline
\end{tabular}

Egypt. J. Bot., Vol. 55, No. 2 (2015) 
The resulting dendrogram, revealed by protein analysis (Fig. 3) shows that the studied species are presented as two main clusters at an average distance of 0.37 . The first cluster includes $F$. cretica represented as a delimited species at 0.396 . In the rest of cluster $F$. arabica at 0.6300 represented also as a separated species while the four Zygophyllum species are differentiated at 0.7515 into two sub cluster. The first sub-cluster includes Z. album and the second one includes the rest of Zygophyllum sp. at 0.9675 . The second cluster is differentiated at 0.4350 into $N$. retusa and the rest of species; P. harmala and $T$. terrestis are represented as sub cluster at 0.6705 .

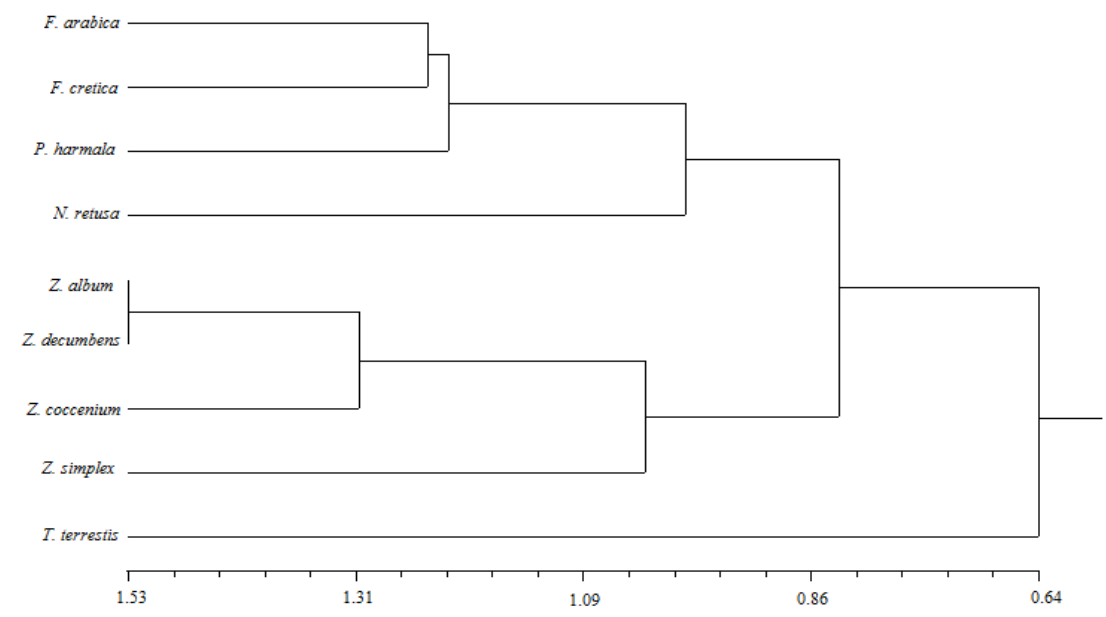

Fig. 2. Dendrogram of the studied species based on pollen grain characters.

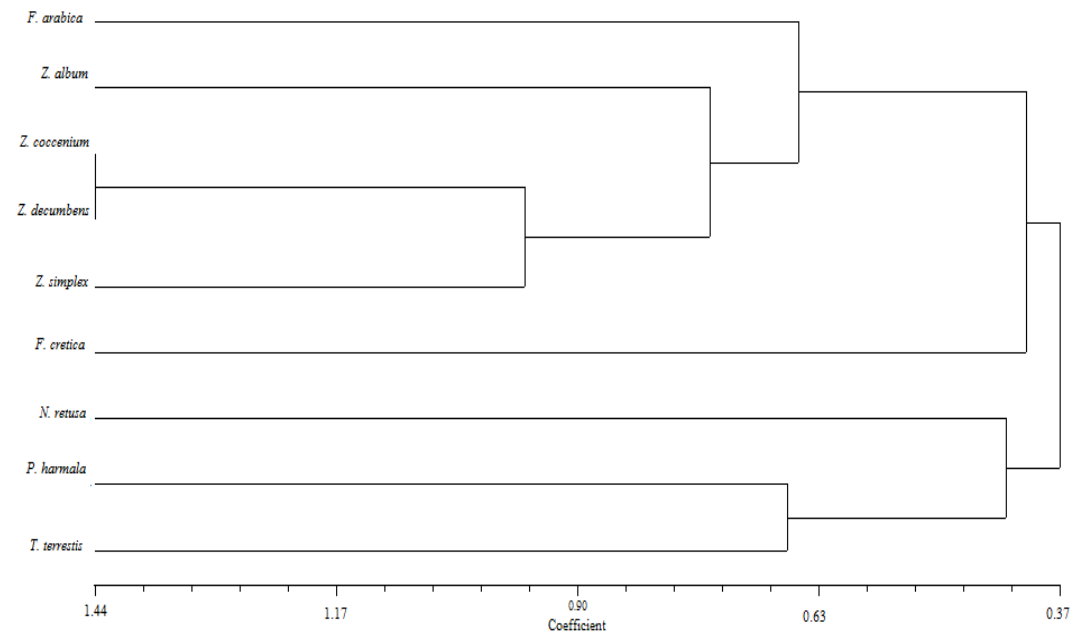

Fig. 3. Dendrogram studied species based on pollen.

Egypt. J. Bot., Vol. 55, No. 2 (2015) 


\section{Discussion}

The above results showed that $T$. terrestis is separated completely from the studied taxa belonging Zygophyllaceae family. This may be due to changes in pollen morphology which is affected by environmental stresses and human impact (October 6 City). In this respect, Sailaja et al., 2005 who stated that pollen can be shrivelled under the temperature and radiation treatment compared with the pollen from plants grown under control conditions. Similarity, the pollen morphological aberrations observed at high temperature stress (Cross et $a l ., 2003$ ) and water deficit stress (Shen and Webster, 1986) might have resulted in abnormal exine with deeply pitted and smooth regions. It is generally considered that for taxonomic purposes the best results are achieved by combining evidence from as many different fields or levels of organization as possible such as morphological, biochemchal and molecular markers. Then, taking into account that the analysis of pollen can offer another tool for the taxonomic characterization of species. Stanley and Linskens (1974) concluded that pollen exine pattern is so genetically stable for the different plant species that it can be used for species identification in recent and in fossil pollens.

The composition of seed proteins is highly stable and affected only slightly by environmental conditions or seasonal fluctuations (Ladizinsky \& Hymowitz, 1979). Seed proteins are mainly storage proteins and not likely to be changed in dry mature seed. The use of seed protein electrophoresis is supported by the fact that mature seeds possess the same protein components and this provide valid evidence for relationships of plants (Emre et al., 2006; Emre, 2009; Vural et al., 2009, Khafagi, 2012, Pragati \& Sreenath, 2013 and Anitalakshmi et al., 2014).

In the present investigation, no common protein bands were observed between the nine studied taxa while, 29 polymorphic bands were recorded showing $100 \%$ polymorphism. The highest band number (14) was scored in the banding profile of $P$. harmala, while the lowest number (5) was found in Fagonia cretica indicating high genetic variation between the studied taxa. On the other hand, some species-specific protein bands were recorded characterized some species e.g. positive unique bands with molecular weight of 64.6, 60.7 and $36.0 \mathrm{KDa}$ are specific to $N$. retusa. The UPGMA protein dendrogram separated $N$. retusa, $P$. harmala and $T$. terrestis in single cluster indicating that protein analysis confirmed the above results obtained and it is useful markers for the identification at the species level. Similar results obtained with Youssef (1990) who studied the genetic relations among eleven species of genus Vicia and four varieties of Vicia faba using SDS-PAGE. The results should some similarities among the examined varieties of $V$. faba and each of the different species showed distinguishable protein profiles. Some species- specific protein bands were recorded in certain studied. Pragati \& Sreenath (2013) showed that seed protein profile among nine species of Ipomoea revealed some bands that are characteristic and constant markers for each species. 
In this study, the UPGMA dendograms obtained from pollen grain or protein agreed more or less with combined dendrogram resulted from RAPD and ISSR analysis on the same nine studied species (EL-Atroush et al., 2014). The results of this study is agreement with Hussein et al., (2009) who found that the macroand micro-morphological as well as phytochemical criteria encourage the separation of $N$. retusa from Zygophyllaceae.

\section{Conclusion}

The present data which is achieved by combining taxonomic tools from pollen grain, molecular (RAPD and ISSR) and total seed protein analysis agreed with Hussein et al. (2009) and Kadry (2012) who separated each Nitraria retusa and Peganum harmala into a distinct family respectively besides Sheahan and Chase (1996 \& 2000) separated Nitraria and Peganum from Zygophyllaceae.

It agreed also with Sheahan and Cutler (1993) and Khalkuziev (1990) who separated Tribulus from Zygophyllaceae and placed in Tribulaceae. The current study recommend to separate the studied species from Zygophyllaceae family except Zygophyllum sp.

Fagonia sp. and Peganum harmala are separated together in a family called Peganiaceae preceding Zygophyllaceae in evolutionary trends.

Nitraria retusa is separated in a family called Nitrariaceae which can be placed between Peganiaceae and Zygophyllaceae.

Finally, Tribulus sp. is placed in a family called Tribulaceae which can be placed after Zygophyllaceae.

Egypt. J. Bot., Vol. 55, No. 2 (2015) 


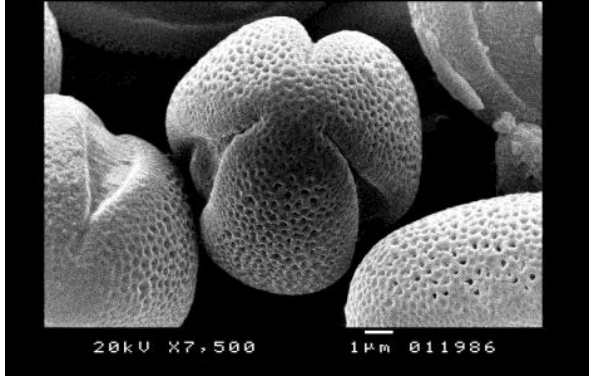

(a)

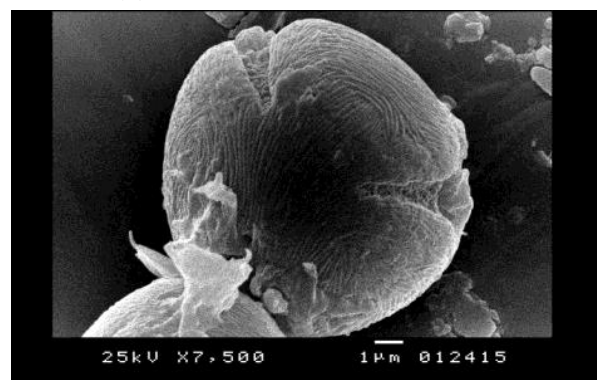

(c)

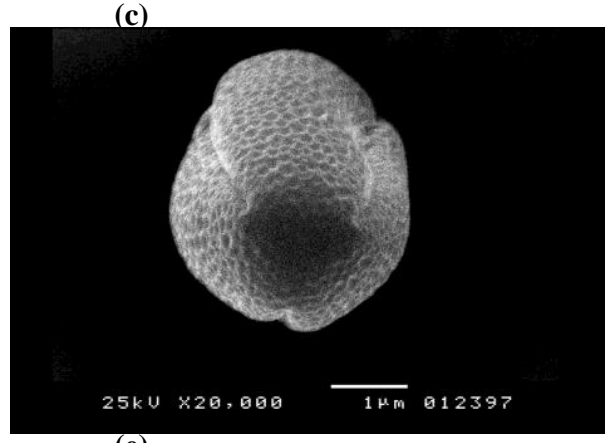

(e)

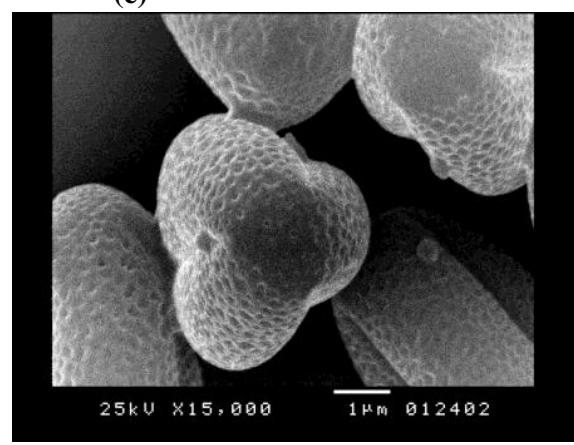

(g)

Plate 1. Polar view of studied pollen grains

a- F arabica,

e- Z. album,

b- F. cretica,

f- Z. coccenium,

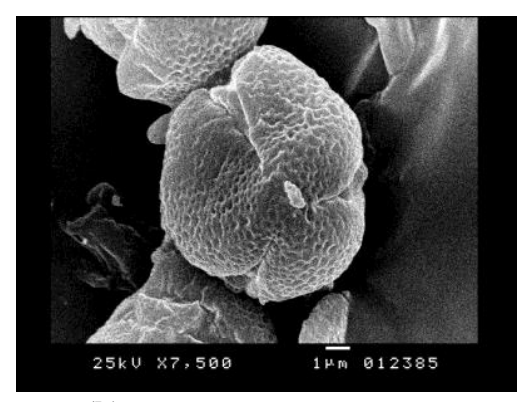

(b)
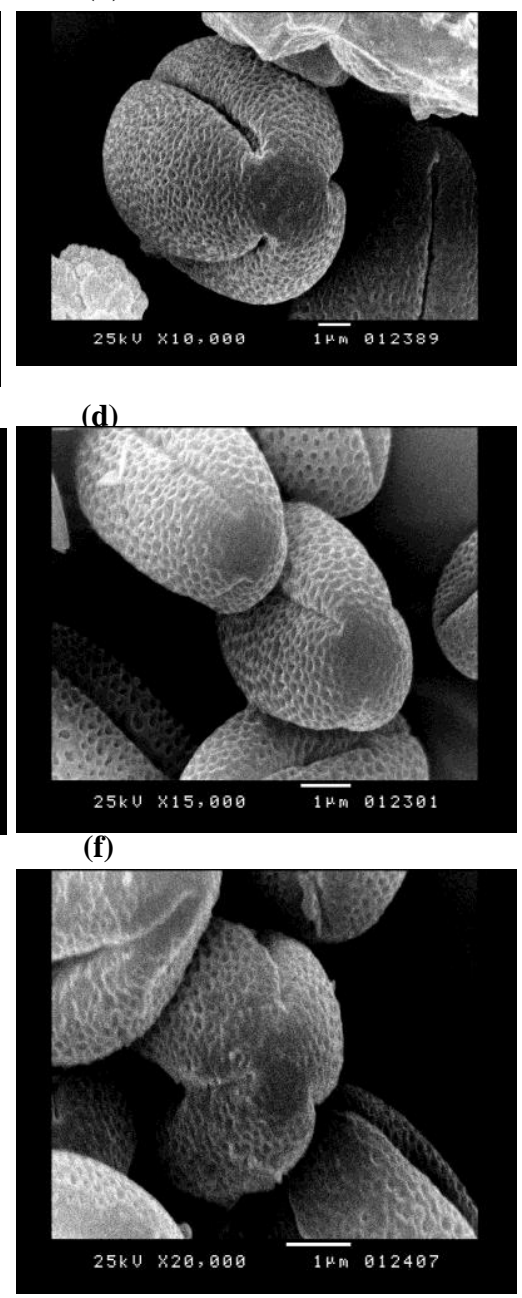

(h)

c- $N$. retusa d- P. harmala g- Z. decumbens h- Z. simplex

Egypt. J. Bot., Vol. 55, No. 2 (2015) 


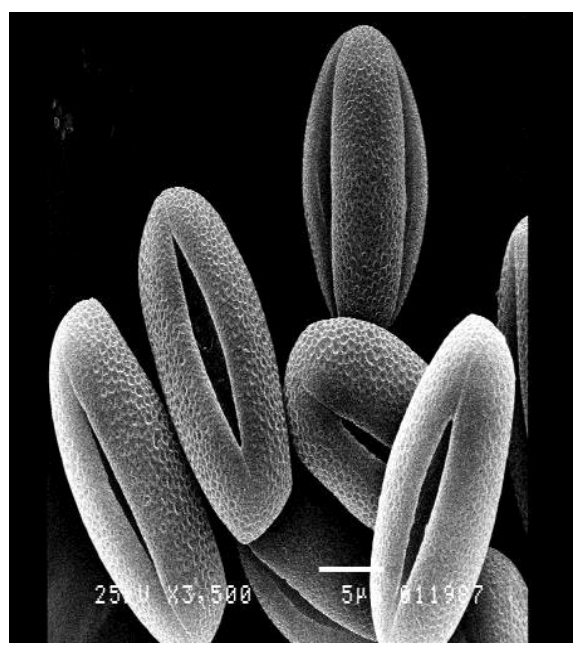

(a)
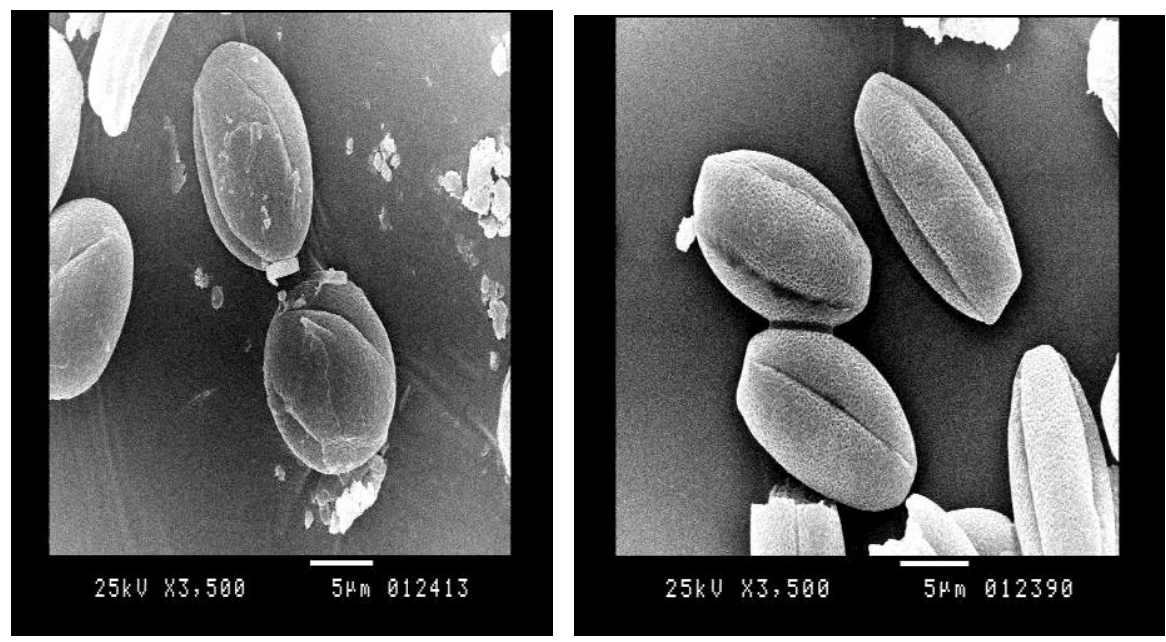

Plate 2. Equatorial view of studied pollen grains (a- F. arabica, b- F. cretica, c- N. retusa and d- P. harmala).

Egypt. J. Bot., Vol. 55, No. 2 (2015)

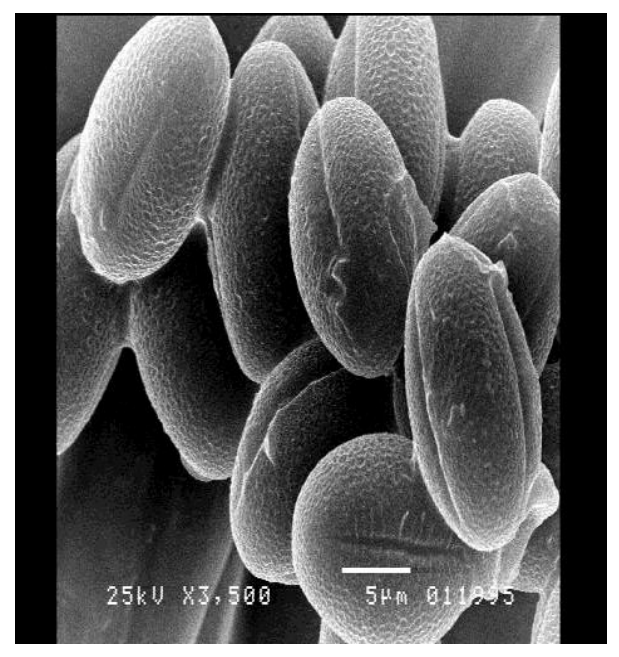

(b) 


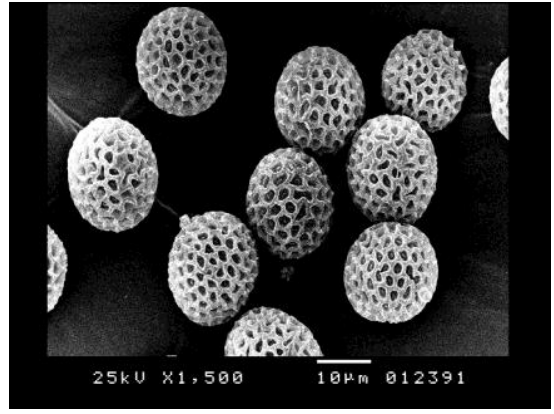

(e)

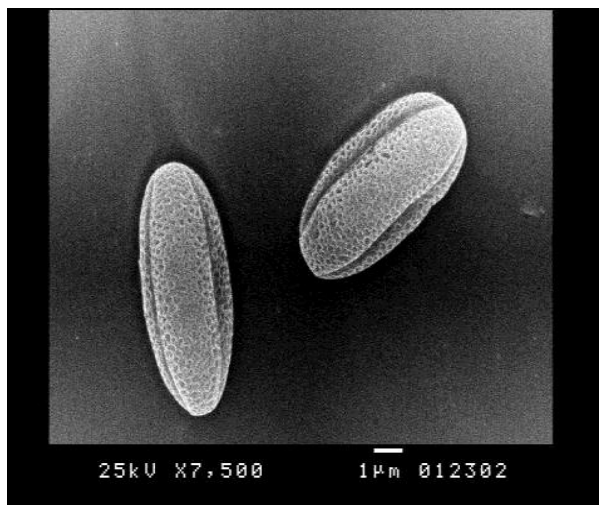

(g)

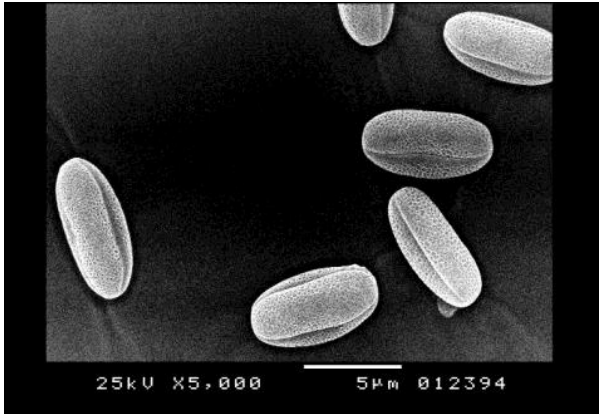

(f)

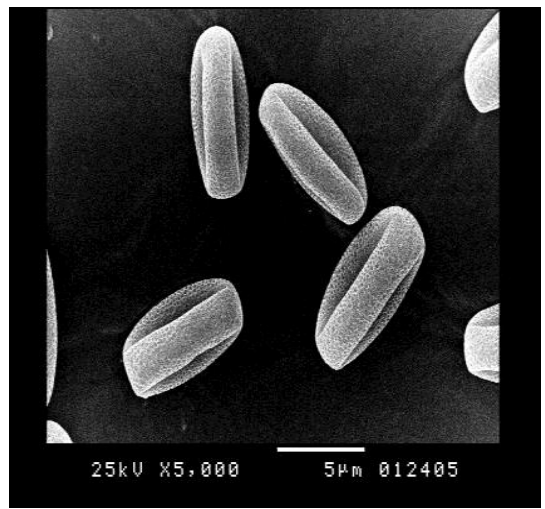

(h)

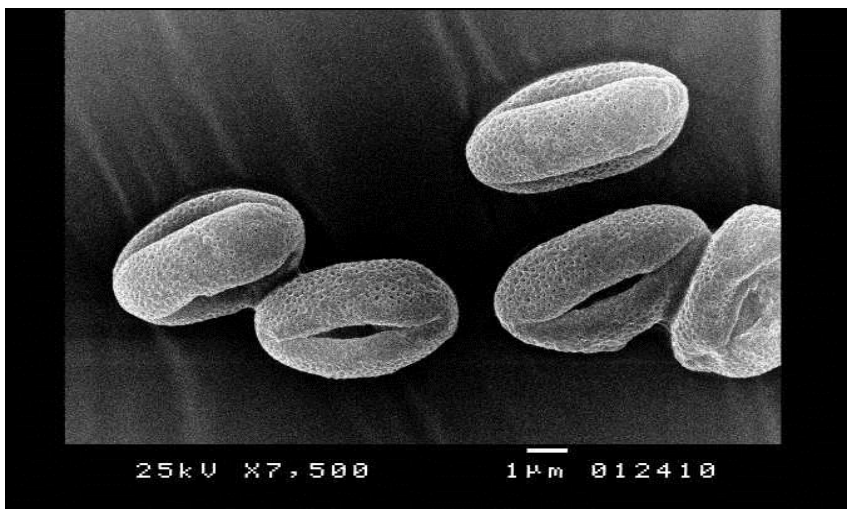

(i)

Plate 2. Cont. Equatorial view of studied pollen grains (e- T. terrestis, f- Z. album, gZ. coccenium, h- Z. decumbens and i- Z. simplex). 


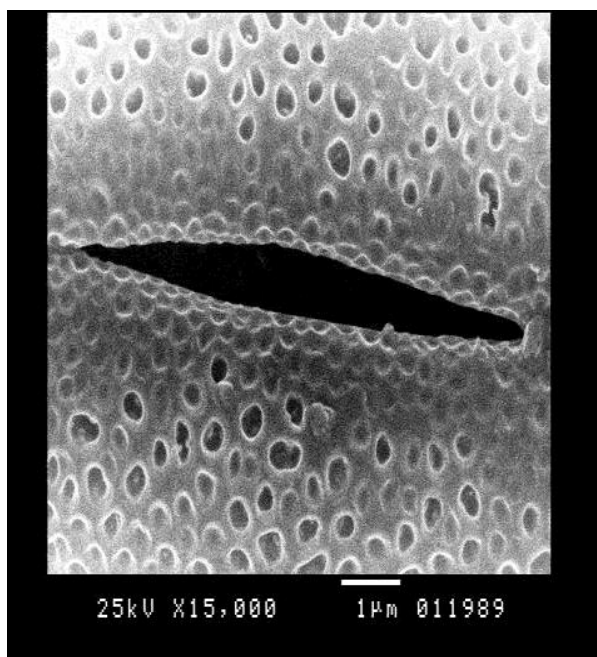

(a)

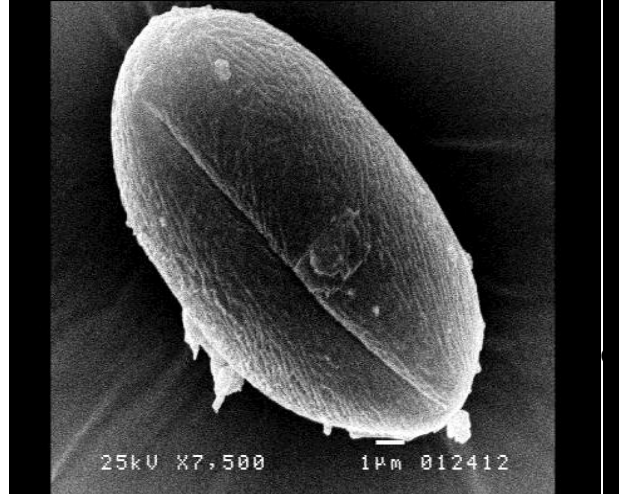

(c)

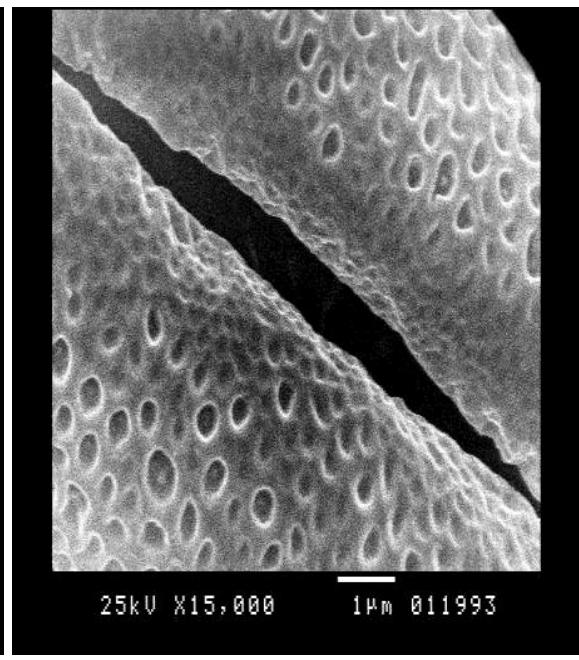

(b)

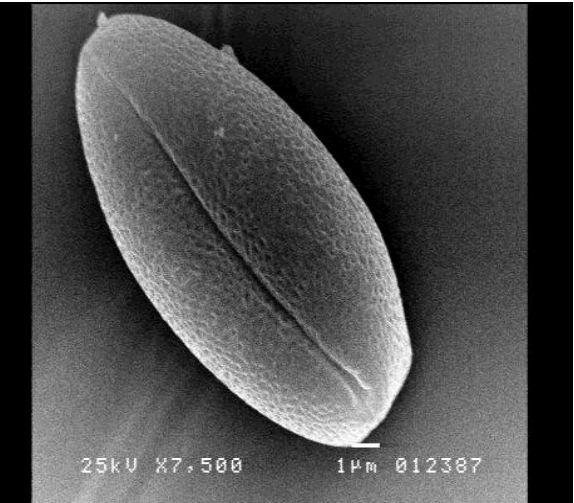

(d)

Plate 3. Aperture of studied pollen grains (a- F. arabica, b- F. cretica, c- N. retusa and d- P. harmala). 


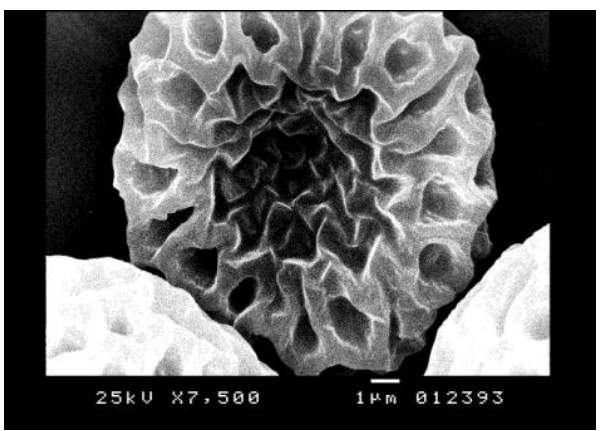

(e)

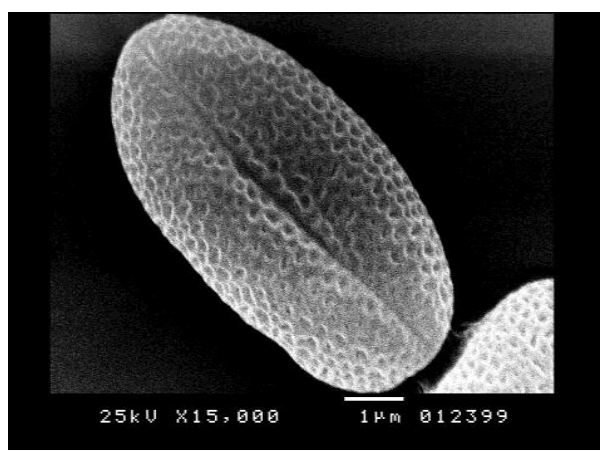

(g)

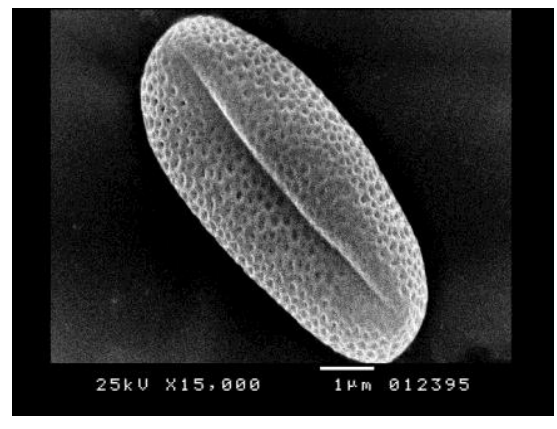

(f)

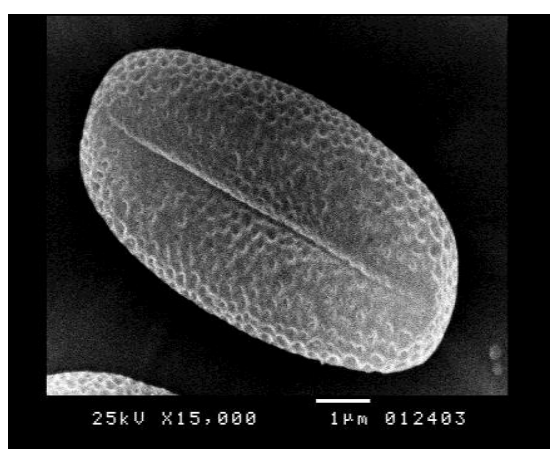

(h)

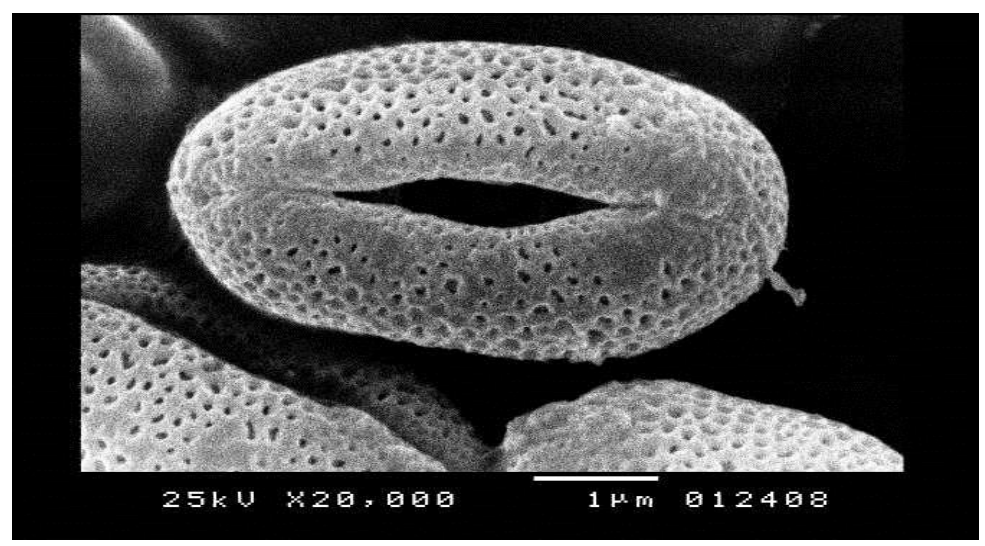

(i)

Plate 3. Cont. Aperture of studied pollen grains (e- T. terrestis, f- Z. album, g- Z. coccenium, h- Z. decumbens and i- Z. simplex). 


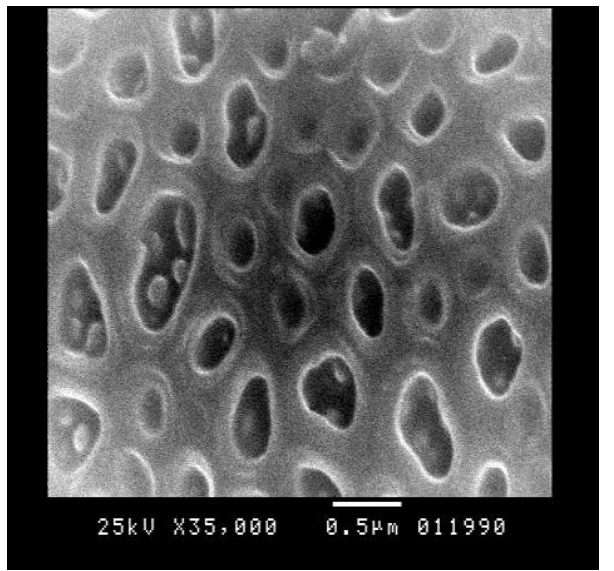

(a)

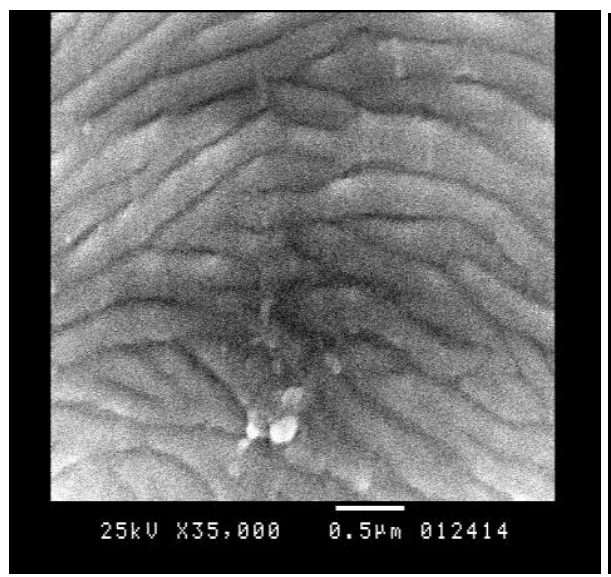

(c)

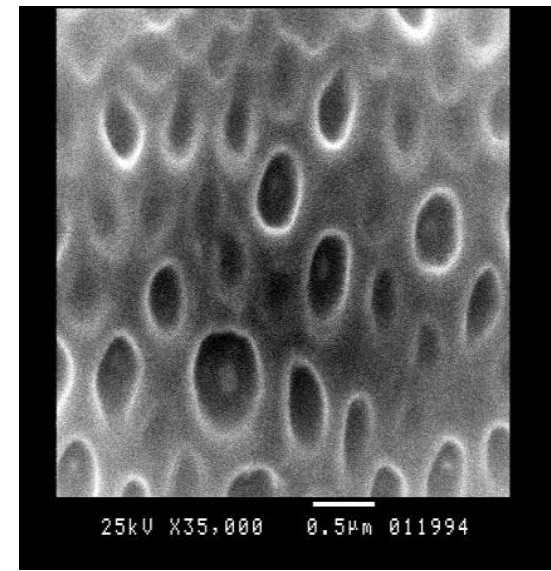

(b)

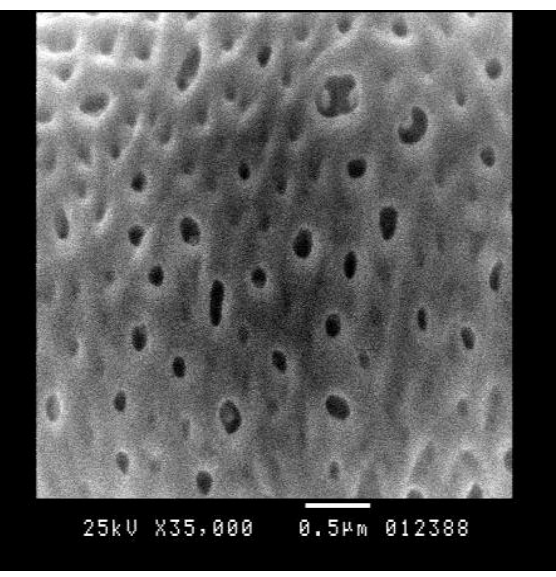

(d)

Plate 4. Sculpturing view of studied pollen grains (a- F. arabica, b- F. cretica, c- $N$. retusa and d- P. harmala). 


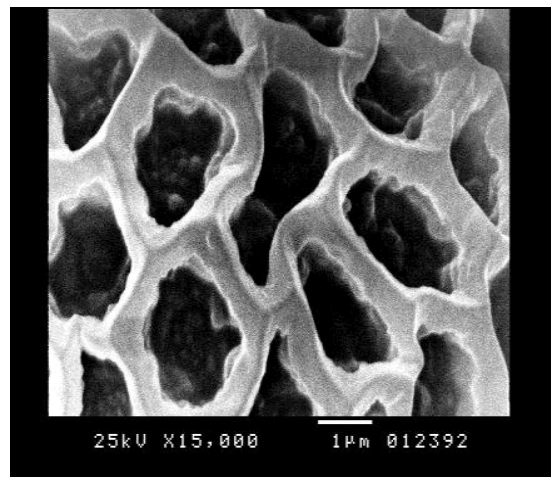

(e)

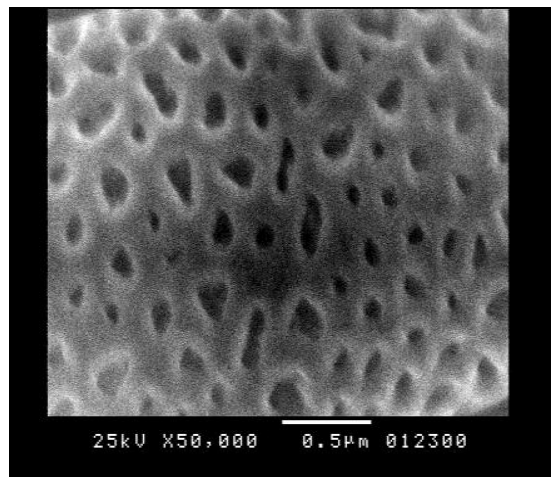

(g)

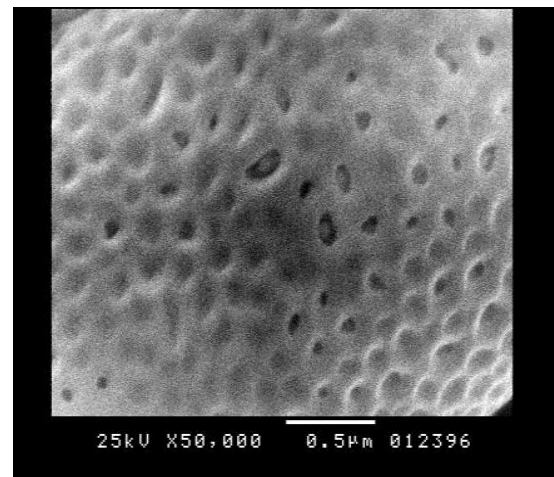

(f)

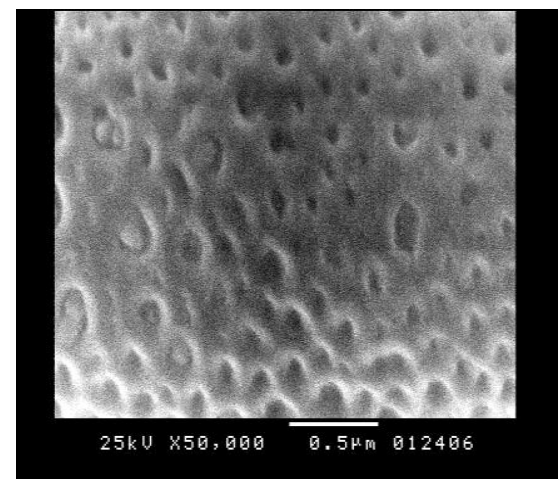

(h)

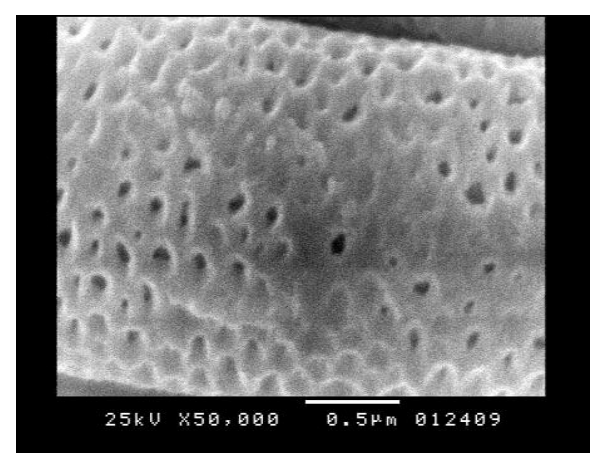

(i)

Plate 4. Cont. Sculpturing view of studied pollen grains (e- T. terrestis, f- Z. album, g$Z$. coccenium, h- Z. decumbens and i- Z. simplex).

Egypt. J. Bot., Vol. 55, No. 2 (2015) 


\section{References}

Abd El-khalik, K. (2012) A numerical taxonomic study of the family Zygophyllaceae from Egypt. Acta Botanica Brasilica., 26 (1): 165.

Anitalakshmi, V., Rame, G., Sathisha, C.S. and Shailaja, H. (2014) Characterization of cultivars based on electrophoretic analysis of seed proteins, isozymes and DNA markers in rice (Oryza sativa L.). Indian J. Plant Sci., 3 (2): 2319.

Badr, A. (1995) Electrophoretic studies of seed protein in relation to the chromosomal criteria and relationships of some taxa of Trifolium. Taxon, 44: 183-191.

Badr, A., El-Shazly, H.H., and Abou-El-Enain, M. (2000) Seed protein diversity and its implications on the relationships in the genus Lathyrus L. (Fabaceae). $1^{\text {st }}$ int. Conf. Biol. Sci. (ICBS) Fac. Sci. Tanta Univ. (May 7-8) 1: 1-15.

Barbara, L., Vincenzo, M. and Nicola, M. (1995) Olive pollen ultrastructure: Characterization of exine pattern through image analysis-Scanning electron microscopy. Scientia Hort., 65 (4): 283-294.

Blackmore, S. (1981) Palynology and inter-generic relationships in sub-tribe Hyoseridine (Compositae: Lactuaceae). Bot. J. Linn. Soc., 82: 1-13.

Boulos, L. (1999) “Flora of Egypt”, Vol. 1. Azollaceae -oxalidaceae. Al Hadara Publishing, Cairo, 417pp.

Boulos, L. (2000) “Flora of Egypt”. Alhadara Publishing, Egypt Vol. 2. Cairo,: 12-18.

Cross, R.H., McKay, S.A., McHughen, A.G. and Bonham-Smith, P.C. (2003) Heatstress effects on reproduction and seed set in Linum usitatissimum L. (flax). Plant Cell Environ., 26: 1013-1020.

Dahlgren, G. (1989) The last dahlgrenogram. System of classification of the dicotyledons. "The Davis and Hedge Festschrift". Edinburgh University Press, Edinburgh, pp 249-260 Tan, K. (Ed.)..

Dahlgren, R. (1980) A revised system of classification of the angiosperms. Bot. J. Linn. Soc., 80: 91-124.

Dahlgren, R. (1983) General aspects of angiosperm evolution and macrosystematics. Nord. J. Bot., 3: 119-149.

Echlin, P. (1968) The use of the scanning reflection electron microscope in the study of plant and microbial material. J. Roy. Microscop. Soc., 88: 407-418.

El-Atroush H., Barakat H.M., Tantawy M.A. and EL-Shabasy A.E. (2014) Molecular characterization of Nitraria retusa and selected taxa of Zygophyllaceae using RAPD and ISSR markers. Egyptian. J. of Genet. and Cytology (under press).

El-Ghamery, A.A., Abdel-Azeem, E. A. and Kasem, A. M. (2003) Electrophoretic seed protein, isozyme patterns and nucleic acids content in some Egyptian taxa of the genus Zygophyllum. Egypt J. Biotechnol., 13: 268-83.

Egypt. J. Bot., Vol. 55, No. 2 (2015) 
Emre, I., Turgut-Balik, D., Genc, H. and Sahin, A. (2006) The use of seed proteins revealed by SDS-PAGE in taxonomy of some Lathyrus L. species grown in Turkey. Pak. J. Bio. Sci., 9 (12): 2358-2361.

Emre, L. (2009) Electrophoretic analysis of some Lathyrus L. species based on seed storage proteins. Genet. Resour. Crop Evol., 56: 31-38.

Engler, A. (1931) Zygophyllaceae. In: Die Natürliche Pfl Anzenfamilien, Engler, A., Prantl, K. Eds. $2^{\text {nd }}$ vol. 19a, section 2: 144-184. Leipzig, Engelmann.

Erdtman, G. (1943) “An Introduction to Pollen Analysis”. Waltham Mass., pp. 239.

Erdtman, G. (1952) "Pollen Morphology and Plant Taxonomy". Angiosperms. Waltham. Chronica Botanica, pp. 222.

Faegri, K. (1956) Recent trends in palynology. Bot. Rev., 22: 639-664.

Ghazanfar, S.A. (1994) "Hand Book of Arabian Medicinal Plants". CRC Press, Boca Raton Ann Arbor, London, Tokyo, pp. 587.

Godwin, H., Echlin, P. and Chapman, B. (1967) The development of the pollen grain wall in Ipomoea purpurea (L.) Roth. Review of Palaeobotany and Palynology, 3: 181195.

Goldberg, A. (1986) Classification, evolution and phylogeny of the families of dicotyledons. Smithson Contrib. Bot., 58:1-314.

Haidar, A.S., Walid, M.F., Mohamed, A. S. and Mohamed, A. B. (2013) Variability of morphological characters, protein patterns and random amplified polymorphic DNA (RAPD) markers in some Pisum genotypes. Afr. J. Agric. Res., 8 (17): 1608-1616.

Hess, M. (1981a) The fine structure of the exine in relation to the stickness of Angiosperm pollen. Rev. Palaeobot. Palynol., 35: 81-92.

Hess, M. (1981b) Pollenkitt and viscin threads: their role in cementing pollen grains. Grana, 20: 145-152.

Hesse, M. (1986) Nature, form and function of pollen-connecting threads in angiosperms, "Pollen and Spores". Blackmore and I.K. Ferguson (Eds.), Academic Press, London. pp.109-18.

Hussein, S.R., Tantawy, M.E., Kawashty, S.A. and Sale, N.A. (2009) Chemosystematic studies of Nitraria retusa and selected taxa of Zygophyllaceae in Egypt. Plant Syst. Evol., 277: 251-264.

Hutchinson, J. (1967) "The Genera of the Flowering Plants". Clarendon Press, Oxford. pp. 34.

Khafagi, A.A.F. (2012) The taxonomic significance of seed proteins in Zygophyllum species (Zygophyllaceae) in Egypt. Egypt. J. Biotechnol.,15: 1. 
Khafagi, A.A. (2003) The significance of seed proteins in Zygophyllum species (Zygophyllaceae) in Egypt. Egypt J. Biotechnol., 15: 186-94.

Khalkuziev, P. (1990) Orodstvennykh svyazyahk nekotorykh semeistv rastenii pustynnykh oblastei. Dissertation, Tashkent. pp. 114.

Konarev, V. G. (1983) Belki rastenii kak geneticheskie marker Plant Proteins As Genetic Markers", Moscow: Nauka., pp. 14.

Kremp, G.O.W. (1968) Morphologic Encyclopaedia of "Palynology. $2^{\text {nd }}$ ed., Univ. Arizona Press, Tucson. pp. 263.

Kress, W. J. and Stone, D. E. (1982) Natural of the sporoderm in monocotyledons with special reference to the pollen grains Canna and Heliconia. Grana, 21: 129-148.

Kress, W.J. and Stone, D. E. (1983) Morphology and phylogenetic significance of exine-less pollen of Heliconia (Heliconiaceae). Syst. Bot., 8: 149-167.

Ladizinisky, G. and Hymowitz, T. (1979) Seed protein electrophoresis in taxonomic and evolutionary studies. Theor. Appl. Genet., 45: 145-51.

Laemmli, U. K. (1970) Cleavage of structural proteins during the assembly of the head of bacteriophage T4. Nature, 122: 680-5.

Martens, J. and Fretz, T. A. (1980) Identification of eight crab apple by pollen surface sculpture. J. Amer. Hort. Sci., 105 (2): 257-263.

Mohamed, E. Tantawy, Sayed, F. Khalifa; Karima, A. Hamed and Heba, M. Elazab (2005) Palynological study on some taxa of mimosoideae (Leguminosae). Int. J. Agri. Biol. 7 (6): 857.

Mohmed, H. M. (2006) Taxonomic significance of seed proteins and iso-enzymes in Tribulus (Zygophyllaceae). Int. J. of Agri. \& Biol., 8 (5): 573-575.

Moradpour, K., Najaphy, A., Mansoorifar, S. and Mostafaie, A. (2014) Evaluation of leaf protein pattern in wheat genotypes under drought stress. Int. J. Adv. Biol. Biom. Res. 2 (3): 840-846.

Pragati, V.G. P. and Sreenath, K. P. (2013) Phylogenetic relationship of some Ipomoea seed proteins by SDS-PAGE. Int. Res. J. Biol. Sci., 2 (10):64.

Punt, W., Blackmore, S., Nilson, S. and LeThomas, A. (1994) "Glossary of Pollen and Spore Terminology". Found. Ultrecht., pp.71.

Raj, B. (1983) A contribution to the pollen morphology of Verbenaceae. Paleobot. Palynol., 39: 343-422.

Ronse Decraene, L.P. and Smets, E.F. (1991) Morphological studies in Zygophyllaceae. I. The floral development and vascular anatomy of Nitraria retusa. Amer. J. Bot., 78 (10): 1438-1448.

Egypt. J. Bot., Vol. 55, No. 2 (2015) 
Ronse Decraene, L.P. De Laet, J. and Smets, E. F. (1996) Morphological studies in Zygophyllaceae. II. The floral development and vascular anatomy of Peganum harmala. Amer. J. Bot., 83 (2): 201-215.

Sailaja, K.K., Raja, R.K., Reddy, V. R., Kakani, V. G. and Duli, Z. (2005). Interactive effects of carbon dioxide, temperature, and ultraviolet-B radiation on soybean (Glycine $\max$ L.) flower and pollen morphology, pollen production, germination, and tube lengths. J. of Experimental Bot., 56 (412): 725-736.

Savithiry S N. (2014) Analysis of Soybean Seed Proteins Using Proteomics. J Data Mining Genomics Proteomics, 5 (1): 2

Sheahan, M. C. and Chase, M. W. (1996) A phylogenetic analysis of Zygophyllaceae based on morphological, anatomical and $r b c \mathrm{~L}$ DNA sequence data. Botanical $J$. Linnean Society, 122: 279-300.

Sheahan, M. C. and Cutler, D. F. (1993) Contributions of vegetative anatomy to the systematics of Zygophyllaceae R. Br. Botanical J. of the Linnean Society, 113: 227262.

Shen, X.Y. and Webster, B.D. (1986) Effects of water stress on pollen of Phaseolus vulgaris L. J. Am. Soc. Hort. Sci., 111: 807-810.

Skvarla, J.J. (1966) Techniques of pollen and spores electron microscopy. Part I. Staining, dehydration and embedding. Okla. Geol., 26: 179-186.

Stanley, R. G. and Linskens, H. F. (1974) "Pollen in Biochemistry Management. Biology", Springer-Verlag, Berlin and New York. pp.99.

Täckholm, V. (1974) “Student's Flora of Egypt”. Cairo: Cairo University Press. pp. 888.

Thanikaimoni, G. (1986) "Pollen Apertures: Form and Function". Academic Press, London, Blackmore and I.K. Ferguson (Eds.), pp. 119-136.

Van Campo, M. (1966) Pollen et phylogenie. Les bréviaxes. Pollen et Spores, 8: 57-73.

Van Campo, M. (1967) Pollen et classification. Palaeobot. Palynol., 3: 65-71.

Vural, C., Äzcan, S. and Akbulut, M. (2009) New combination Veronica (Scrophulariaceae) based on morphological characters and the seed storage protein polymorphism. J. Syst. Evol., 47 (2): 168-172.

Walker, J. W. and Doyle, J. A. (1975) The bases of Angiosperm phylogeny: Palynology. Annals of the Missouri Botanical Garden, 62: 664-723.

Youseesf, S.S. (1990) Protein profiles as a tool to detect genetic variability among Vicia species. Assiut J. Agri. Sci., 21: 303-317.

Zohary, M. (1972) "Flora Palaestina" (Part II: Text). Jerusalem: The Israel Academy of Sciences and Humanities, Jerusalem, pp. 489. 
Zohary, M. (1987) "Flora Palaestina", part II. The Israel Academy for Science and Humanities, Jerusalem, pp. 244-257.

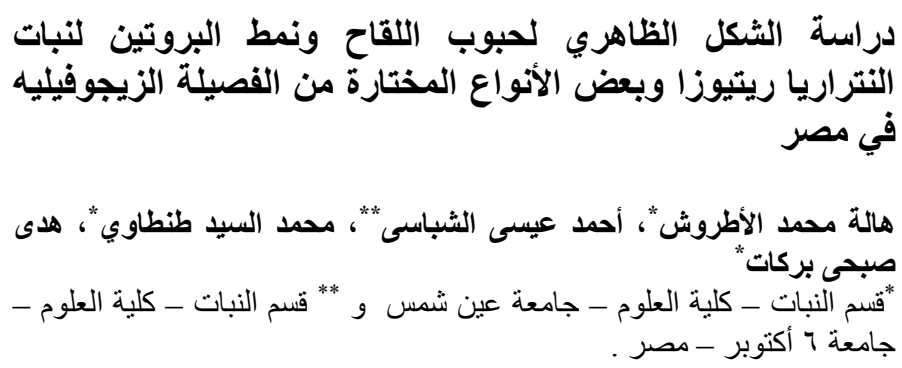

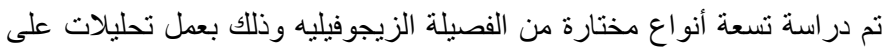

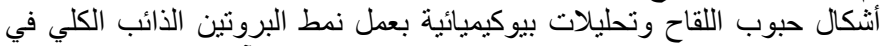

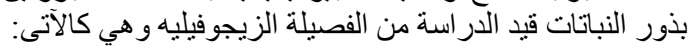

Fagonia arabica, F. cretica, Peganum harmala, Tribulus terrestis,

Zygophyllum album, Z. coccenium, Z. decumbens and Z. simplex

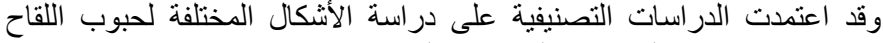

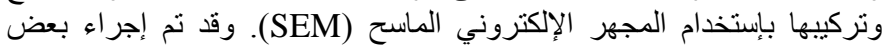

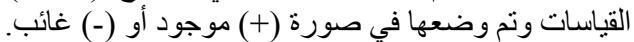

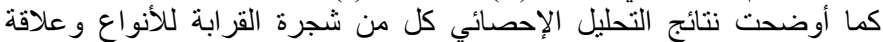

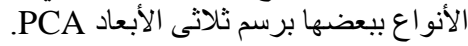

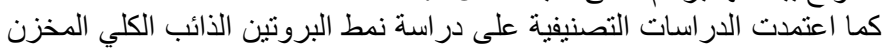

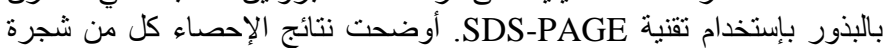

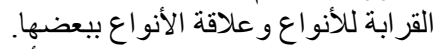

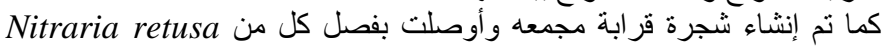

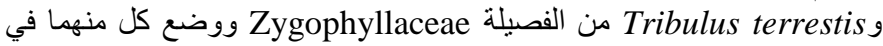
فصيلة مستقلة. 